\title{
The Analysis of the Influence of Financial Performance on Stock Prices with Earning Growth as a Moderating Variable in Infrastructure, Utility and Transportation Sector Companies Listed on the Indonesia Stock Exchange
}

\author{
Melpa Riani ${ }^{1{ }^{*}}$, Iskandar Muda $^{2)}$, Endang Sulistya Rini ${ }^{3)}$ \\ ${ }^{1), 2), 3)}$ Department of Accounting, Faculty of Economics and Business, Universitas Sumatera Utara, Medan, Indonesia
}

\begin{abstract}
This study aims to determine the effect of financial performance on stock prices of infrastructure, utility and transportation companies listed on the Indonesia Stock Exchange. The variables used in this study are stock price as the dependent variable and Current Ratio, Debt to Equity Ratio, Total Assets Turnover, Net Profit Margin, Return on Equity and Price Earning Ratio as independent variables with Earning Growth as a moderating variable. The samples taken were thirty infrastructure, utility and transportation companies listed on the Indonesia Stock Exchange (BEI) in 2010-2019. The data used are the financial statements of each sample company, published through www.idx.co.id and www.financeyahoo.com. The method of analysis used in this research is a quantitative method, with classical assumption testing, and statistical analysis, namely multiple linear regression analysis using a random-effects model. The sampling method used was purposive sampling. The results of this study show that the financial ratios consisting of the TATO, NPM, ROE and PER ratios partially have a positive and significant effect on stock prices. In contrast, CR and DER have no significant effect on stock prices. Earning Growth variable is only able to moderate the effect of NPM on stock prices.
\end{abstract}

Keywords:- Stock Prices, CR, DER, TATO, NPM, ROE, $P E R$, and Earning Growth

\section{INTRODUCTION}

Business development in Indonesia has contributed significantly to the development of other sectors. Industrial companies, for example, have succeeded in producing a variety of products and have obtained higher sales volumes and much higher profits, which in turn have increased company values so that they can use as an alternative investment by potential investors. Investors need information in investing in the capital market to reduce investment uncertainty, estimate future cash flows, and determine what securities to buy and sell so that investors feel safe investing and get returns in the form of returns on their investments. This feeling of security will obtain if investors obtain transparent, unbiased, and timely information as a basis for making their investment decisions. Irham argues that "A capital market is a place where capital funds such as equity and debt securities are trades" (Fahmi, 2012: 34).

One of the most common investments in the capital market today is investing in stocks. The motive of investors to invest in the stock market is to get returns in the form of dividends or capital gains and company ownership. Before investing, investors will consider the return on shares they will receive and the value of the company. The share price represents the company value of a public company. (Suhadak, Kurniaty, Handayani \& Rahayu, 2018). "Capital gain is the positive difference between the selling price and the buying price" (Hermuningsih, 2012: 80). "The stock price depends on many factors, such as earnings per share, dividend per share, payout ratio, company size and stock returns, management, diversification, and others" (Velankar, Chandani \& Ahuja, 2017).

Since the beginning of 2019, infrastructure sector stocks have attracted the eye because they continue to go green. The development and development of the toll road infrastructure sector, which is one of the visions and missions of the government, is one of the causes of economic growth because it increases the use of transportation facilities and the growth of motorized vehicles. The increase in the infrastructure sector places it as the sector with the highest growth compared to other sectoral indices. Based on data from the Indonesia Stock Exchange website, since the beginning of 2019, this index has increased to $10.11 \%$. The increase in stock prices of infrastructure issuers cannot be separated from fundamental factors because the financial reports released by several listed companies in the industrial sector have shown excellent performance.

An increase in stock prices is often misunderstood as an increase in company profits, so that company managers, as agents of the company, always try to increase the company's profits as much as possible. The reputation of company managers is reflected in an increase in company profits, followed by an increase in share prices-finally, the owner's wealth increases, followed by better prosperity for shareholders. Shareholders or investors will always motivate company managers to work hard and run any 
program to increase the company's share price. Increasing the share price can be done by expanding the company's profit through investing in projects that are sure to provide a higher return on the capital invested in these projects. An increase in company profits motivates shareholders to ask for profit-sharing in the form of dividends (Blazenko and Yufen, 2012). However, many companies increase corporate profits but do not distribute dividends because increased profits can cause by increased debt and company profits are used to cover capital expenditure costs which reduce the company's growth ratio.

The share price is the value of a share that reflects the wealth of the company that issued the shares, where changes or fluctuations are determined mainly by the power of supply and demand that occurs on the stock exchange (secondary market). The more investors who want to buy or keep a stock, the price will increase, conversely, the more investors who wish to sell or release a stock, the price will move down. The risk of a shareholder is when the share price decreases. Thus, an investor must be able to predict these risks. To overcome the risks faced from changes in share prices, an investor can use the information contained in financial reports to assess the company's financial performance.

Financial performance shows how effective and efficient an organization is in achieving its goals. Effectiveness refers to the ability of management to select objectives or accurate instruments to achieve specific objectives. Efficiency refers to the ratio between input and output at which a suitable input will produce the optimal output. Improving financial performance is a requirement for companies to attract investors. Published financial reports represent the financial performance of a company. Financial statements are the final result of the accounting process carried out to provide information about the financial condition of a company. Investors or managers use reports to make decisions about investment (Suhadak, Kurniaty, Handayani \& Rahayu, 2018).

\section{II. LITERATURE REVIEW}

\section{A. Signalling theory}

Information published as an announcement will provide a signal for investors in making investment decisions. If the statement contains a positive value, it expects that the market will react when the announcement is received by the market (Jogianto, 2000: 570). Market reactions aimed at changes in share trading volume. When the information announces, and all market players have received the information, market participants first interpret and analyze the information as a good signal (good news) or a bad signal (bad news). If the announcement is a good signal for investors, there will be a change in the share trading volume. Statement of accounting information provides a signal that the company has good prospects in the future (good news) so that investors are interested in trading stocks; thus the market will react as reflected by changes in the volume of stock trading.

\section{B. Efficiency Market Hypothesis}

Efficient market theory or the Efficient Market Hypothesis (EMH) states that the prices of shares and other assets automatically combine all available information and adjust quickly to include new information. Capital market efficiency (Efficient Market) is a condition in which a stock price fits promptly with additional information, and therefore the stock price includes all available information (Relly \& Brown, 2012: 139). The more appropriate the share price with market information, the market condition perfectly formes. In general, according to Relly \& Brown (2012: 140), market prices will adjust to the information obtained. These adjustments can be over-adjusted or underadjusted than it should be. It is due to the decision to buy and sell by investors on the information received to maximize profits.

\section{Stock price}

According to Tandon and Malhotra (2013), the share price is the cost required to buy securities on the stock exchange. The stock price depends on many factors, such as earnings per share, dividends per share, payout ratio, company size and dividend yield, management, diversification, and others. Investments in stocks offer liquidity benefits as well as opportunities for high returns. Stock price movements are not independent, and extrinsic or intrinsic factors influence stock price movements.

\section{Financial performance}

According to Jumingan (2014: 239), financial performance is a description of the financial condition in a certain period, both regarding the aspects of raising funds and channelling funds which are usually measured by indicators of capital adequacy, liquidity and profitability. The communication of financial performance information has relevance in evaluating the potential changes in economic resources controlled or controlled by the company in the future. Annual reports help anticipate the company's capacity to generate cash flow using existing resources as well as assess management quality. Especially, shareholders and potential investors are interested in the size of the company's current or future beneficiaries, which guarantees future dividends and achieves value-added capital (Anghel \& Man, 2014).

\section{Current ratio}

The current ratio (Current Ratio) is a ratio to measure the company's ability to pay short-term obligations or debts that are due immediately when they collect as a whole (Kasmir, 2014: 134).

Current ratio $=\frac{\text { Current Assets }}{\text { Current Liabilities }} \times 100 \%$

\section{$>$ Debt to equity ratio}

Debt Equity Ratio is an instrument to determine the ability of a company's equity or net assets to pay off all of its liabilities. It shows that the higher the percentage of foreign capital used in the company's operations or the business capital structure, the more it uses debt relative to equity (Munawir, 2013: 158). 
Debt to equity ratio $=\frac{\text { Total Debt }}{\text { Total Equity }} \times 100 \%$

\section{Total assets turnover}

Total Assets Turnover, according to Brigham and Houston (2010: 139), is a ratio that measures the turnover of all company assets and is calculated by dividing sales by total assets.

Total Assets Turn Over $=\frac{\text { Sales }}{\text { Average Assets }}$

\section{Net profit margin}

According to Muhardi (2013: 64), the net profit margin reflects the company's ability to generate net profit from each sale. The higher the net profit margin value, the better the company's performance.

Net profit margin $=\frac{\text { Earning After Tax }}{\text { Sales }} \times 100 \%$

\section{Return on equity}

According to Kasmir (2013: 204) "Return on Equity (ROE) is a ratio to measure net profit after tax with own capital". Return on Equity (ROE) is a ratio to measure management's ability to manage existing capital to earn net income.

Return on equity $=\frac{\text { Earning After Tax }}{\text { Equity }} \times 100 \%$

\section{Price earning ratio}

According to Rahardjo (2009: 151), "the price earning ratio is often used to compare investment opportunities." A ratio of price to share income calculates by dividing the market price per share (market price share) by earnings per share (EPS).

Price earning ratio $=\frac{\text { Stock Price }}{\text { EPS }} \times 100 \%$

\section{E. Earnings Growth}

Companies that have increased earnings growth each year will attract investors to invest. The higher the profit generated by the company, the greater the return (dividend) that will be distributed to shareholders. According to Harahap (2010: 309), earning growth is a ratio that describes the percentage growth of company posts from year to year.

$\Delta \mathrm{Yn}=\frac{\mathrm{Yn}-\mathrm{Y}(\mathrm{n}-1)}{\mathrm{Y}(\mathrm{n}-1)} \times 100 \%$

\section{F. Framework}

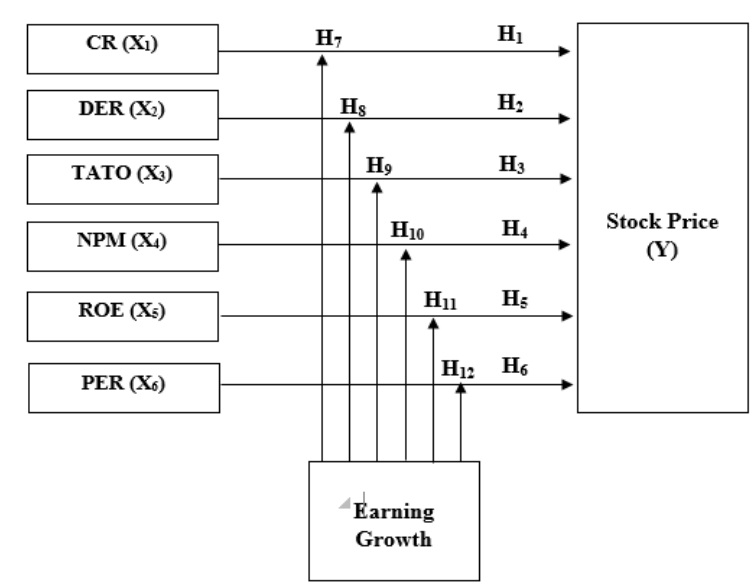

Fig 1

\section{G. Hypothesis}

H1: Current Ratio has a positive and significant effect on stock prices.

H2: Debt to Equity Ratio has a negative and significant effect on stock prices.

H3: Total assets turnover has a positive and significant effect on stock prices.

H4: Net Profit Margin has a positive and significant effect on stock prices.

H5: Return on assets has a positive and significant effect on stock prices.

H6: Price earning ratio has a positive and significant effect on stock prices.

H7: Earning Growth can moderate the effect of the Current Ratio on stock prices.

H8: Earning Growth can moderate the effect of the debt to equity ratio on stock prices.

H9: Earning Growth can moderate the effect of total asset turnover on stock prices.

H10: Earning Growth can moderate the effect of net profit margin on stock prices.

H11: Earning Growth can moderate the effect of return on assets on stock prices.

H12: Earning Growth can moderate the effect of the price earning ratio on stock prices.

\section{RESEARCH METHODOLOGY}

\section{A. Research Approach}

This type of research is causal associative research to determine the effect of financial performance on stock prices. According to Umar (2003: 30), the causal associative study aims to analyze the relationship between one variable and another so that it knows how one variable affects other variables.

\section{B. Data Analysis Methods}

The data analysis method used in this study is a statistical analysis method using Eviews9 software. Data analysis performs by testing standard assumptions and testing hypotheses. 


\section{RESULT}

\section{A. Regression Equations}

In this research, regression analysis uses to determine whether there is an influence of independent variables, namely current ratio, debt to equity ratio, total assets turnover, net profit margin, return on equity, and price earning ratio on the dependent variable, it is a stock price with earning growth as a moderating variable.

\begin{tabular}{|c|c|c|c|c|}
\hline Variable & Coefficient & Std. Error & t-Statistic & Prob. \\
\hline C & & & 6.671376 & 0.0000 \\
\hline LOGCR & 4.455502 & 0.667854 & 0.712178 & 0.4773 \\
\hline LOGDER & 0.050760 & 0.071275 & 0.039253 & 0.9687 \\
\hline LOGTATO & 0.003509 & 0.089389 & 3.051354 & 0.0026 \\
\hline LOGNPM & 0.212469 & 0.069631 & 3.352822 & 0.0010 \\
\hline LOGROE & 0.225800 & 0.067346 & 2.275387 & 0.0241 \\
\hline LOGPER & 0.169707 & 0.074584 & 7.306198 & 0.0000 \\
\hline R-squared & 0.340126 & 0.046553 & & 0.96859 \\
\hline Adjusted R-squared & 0.313417 & Mean dependent var & 0.58285 \\
\hline S.E. of regression & 0.480981 & S.D. dependent var & 39.3282 \\
\hline F-statistic & 14.39029 & Sum squared resid & 1.16184 \\
\hline Prob(F-statistic) & 0.000000 & Durbin-Watson stat & \\
\hline
\end{tabular}

Table 1:- Results of Regression Analysis

\section{B. Partial Significance Test (Statistical Test $-t$ )}

$>$ Prob CR which is worth 0.4773 is higher than the Sig t value of $5 \%$ indicating that the effect of $\mathrm{CR}$ on stock prices is not significant, so $\mathrm{H} 1$ is rejected, meaning that $\mathrm{CR}$ has a positive and insignificant effect on stock prices.

$>$ Prob DER which has a value higher than $5 \%$, which is equal to 0.968 , indicates that DER has no significant effect on stock prices, so $\mathrm{H} 2$ is rejected, meaning that DER has a positive and insignificant effect on stock prices.

$>$ The probability that TATO has a value less than 5\%, which is equal to 0.0026 , indicates that TATO has a significant effect on stock prices so that $\mathrm{H} 3$ is accepted, which means that TATO has a positive and significant effect on stock prices.

The probability of NPM is less than the sig t value of $5 \%$, which is 0.001 , which indicates that NPM has a significant effect on stock prices so that $\mathrm{H} 4$ is accepted, which means that NPM has a positive and significant effect on stock prices.

The ROE Probability value is 0.0241 which is smaller than sig t 0.05 so that ROE has a significant effect on stock prices, so $\mathrm{H} 5$ is accepted, which means ROE has a positive and significant effect on stock prices.

The Prob PER value is less than 0.05 , namely 0.00 , so that H6 is accepted, the effect of PER on stock prices is significant, meaning that PER has a positive and significant effect on stock prices.

\section{Coefficient of Determination}

The statistical test of the coefficient of determination in this study aims to determine how far the model's ability of the model explains the dependent variable's variation. Statistical test results of the coefficient of determination can see in Table 1.

Table 1. shows that the Adjusted R Square value of 0,336823 or $33,6823 \%$, which means that the percentage of influence of the independent variable (current ratio, debt to equity ratio, total assets turnover, net profit margin, return on equity, and price earning ratio) to the stock price is the value of the coefficient of determination or $66,3177 \%$. In comparison, the remaining $66,3177 \%$ is influenced or explained by other variables not included in this research model.

\section{Moderate Regression Analysis (MRA) Test}

MRA test is used to test the hypothesis (7-12), namely that earning growth can moderate the influence between current ratio, debt to equity ratio, total assets turnover, net profit margin, return on equity, and price earning ratio on the stock price. Here are the results of calculations using Eviews: 
ISSN No:-2456-2165

\begin{tabular}{|c|c|c|c|c|}
\hline Variable & Coefficient & Std. Error & t-Statistic & Prob. \\
\hline $\mathrm{C}$ & 4.209188 & 0.658487 & 6.392211 & 0.0000 \\
\hline LOGCR & 0.064088 & 0.071457 & 0.896872 & 0.3711 \\
\hline CREG & $-2.18 \mathrm{E}-05$ & $4.90 \mathrm{E}-05$ & -0.443944 & 0.6577 \\
\hline LOGDER & 0.036362 & 0.090064 & 0.403733 & 0.6869 \\
\hline DEREG & $5.67 \mathrm{E}-05$ & $3.86 \mathrm{E}-05$ & 1.466295 & 0.1445 \\
\hline LOGTATO & 0.233134 & 0.069510 & 3.353944 & 0.0010 \\
\hline TATOEG & -0.001706 & 0.004601 & -0.370855 & 0.7112 \\
\hline LOGNPM & 0.284654 & 0.072490 & 3.926811 & 0.0001 \\
\hline NPMEG & -0.002922 & 0.001375 & -2.124705 & 0.0351 \\
\hline LOGROE & 0.160609 & 0.080614 & 1.992315 & 0.0480 \\
\hline ROEEG & -0.001897 & 0.001652 & -1.148162 & 0.2526 \\
\hline LOGPER & 0.335097 & 0.045021 & 7.443078 & 0.0000 \\
\hline PEREG & $1.28 \mathrm{E}-05$ & $1.67 \mathrm{E}-05$ & 0.763810 & 0.4461 \\
\hline R-squared & 0.396880 & \multicolumn{2}{|c|}{ Mean dependent var } & 1.1414 \\
\hline Adjusted R-squared & 0.352749 & \multicolumn{2}{|c|}{ S.D. dependent var } & 0.5971 \\
\hline S.E. of regression & 0.478213 & \multicolumn{2}{|c|}{ Sum squared resid } & 37.504 \\
\hline F-statistic & 8.993286 & \multicolumn{2}{|c|}{ Durbin-Watson stat } & 1.1421 \\
\hline Prob(F-statistic) & 0.000000 & & & \\
\hline
\end{tabular}

Table 2:- Results of Regression Analysis with Moderating Variable

From the Eviews calculations, it can conclude the influence of the moderation variable is as follows:

$>$ The CREG coefficient of -2.18 means that EG weakens the effect of CR on stock prices. Prob CREG which is worth 0.6577 is higher than the Sig t value of $5 \%$, indicating that the effect of $\mathrm{CR}$ on stock prices moderated by EG is not significant, so $\mathrm{H} 7$ is rejected, meaning that EG weakens the effect of $\mathrm{CR}$ on stock prices in infrastructure, utility and transportation companies listed in IDX however not significant.

The DEREG coefficient of 5.67 means that EG strengthens the influence of DER on stock prices. Prob DEREG which is worth greater than $5 \%$ which is equal to 0.145 indicates that the effect of DER on stock prices as moderated by EG is not significant, so H8 is rejected, meaning that EG strengthens the effect of DER on stock prices but is not significant.

$>$ TATOEG coefficient of -0.001 means that EG weakens the influence of TATO on stock prices. The probability of TATOEG which has a value higher than $5 \%$, which is equal to 0.7112 , indicates that the effect of DER on the stock price as moderated by EG is not significant, so $\mathrm{H} 9$ is rejected, meaning that EG weakens the influence of TATO on stock prices but is not significant.

$>$ The NPMEG coefficient of -0.002 means that EG weakens the influence of NPM on stock prices. The probability of NPMEG which has a small value of greater than $5 \%$, which is equal to 0.035 , indicates that the effect of NPM on the stock price as moderated by EG is significant, so H10 is accepted, meaning that EG weakens the influence of NPM on stock prices and is significant.

$>$ ROEEG coefficient -0.001 means that EG weakens the effect of ROE on stock prices. The ROEEG Prob value of 0.252 which is higher than sig t 0.05 indicates that the effect of ROE on stock prices as moderated by EG is not significant, so $\mathrm{H} 11$ is rejected, meaning that EG weakens the effect of ROE on stock prices but is not significant.

$>$ The PEREG coefficient of 1.28 means that EG strengthens the influence of PER on stock prices. Prob PEREG which has a value higher than 5\%, which is equal to 0.441 , indicates that the effect of PER on stock prices as moderated by EG is not significant, so H12 is rejected, meaning that EG strengthens the effect of PER on stock prices but is not significant.

\section{CONCLUSION AND RECOMMENDATION}

\section{A. Conclusions \\ $>$ The effect of the Current Ratio on stock prices}

CR has a coefficient of 0.05 which means that CR has a positive effect on stock prices in infrastructure, utility and transportation sector companies listed on the Indonesia Stock Exchange. If CR increases by $1 \%$, the share price will increase by $\mathrm{Rp}$. 0.05 . It shows that $\mathrm{CR}$ is directly proportional to the stock price. Prob CR, which is worth 0.4773 , is higher than the Sig t value of $5 \%$, thus indicating that the effect of CR on stock prices is not significant. Research conducted by Adiputra \& Hermawan (2020) provides results that $\mathrm{CR}$ has an insignificant impact on stock prices.

\section{The Effect of Debt to Equity Ratio on stock prices}

DER has a coefficient of 0.003 which means that DER has a positive effect on stock prices in infrastructure, utility and transportation sector companies listed on the Indonesia Stock Exchange. An increase in DER by $1 \%$ will increase the share price by Rp. 0.003. It shows that DER is directly proportional to stock prices. Prob DER with a value higher than $5 \%$, which is equal to 0.968 indicates that DER has a positive and insignificant effect on stock prices. High or 
low debt does not necessarily affect investors' interest in investing their shares, because investors see how much the company can use its liability for the company's operational costs, if the company manages to use debt for operational costs it will give a positive signal for investors to invest in the company. And stock prices will rise; on the other hand, if the company fails to take advantage of its debt, it will give negative signals for investors (Wicaksono, 2015). Research conducted by Pernamasari et al. (2020) shows that DER has a positive effect on stock prices.

\section{$>$ The Effect of Total Assets Turnover on stock prices}

TATO has a coefficient of 0.212 which means that TATO has a positive effect on stock prices in infrastructure, utility and transportation sector companies listed on the Indonesia Stock Exchange. TATO, which increases by 1 unit, will increase the share price by Rp. 0.212 . It shows that TATO is directly proportional to the stock price. The probability of TATO, which is worth less than $5 \%$, which is equal to 0.0026 , indicates that TATO has a positive and significant effect on stock prices. It proves that TATO can be used as a reference for determining the amount of share price and in line with the signalling theory, a high TATO value indicates that the effectiveness of a company is getting better, this is captured by investors as a good signal, to attract investors to invest in the company which will ultimately increase the company's share price. Herawati \& Putra (2018) provide TATO research results that have a positive and significant effect on stock prices.

\section{$>$ The effect of Net Profit Margin on stock prices}

Net profit margin has a coefficient of 0.225 , meaning that NPM has a positive effect on stock prices in infrastructure, utilities and transportation companies listed on the Indonesia Stock Exchange. If the NPM increases by $1 \%$, the share price will increase by Rp. 0.225 . It shows that NPM is directly proportional to the stock price. Prob NPM is less than the sig $\mathrm{t}$ value of $5 \%$, which is 0.001 , which indicates that NPM has a significant effect on stock prices, so it can conclude that NPM has a positive and significant effect on stock prices. With a substantial net profit, there will be more opportunities for a company to increase its business capital without going through new debts so that the income earned increases. Increased revenue will result in higher profits so that the opportunity for investors to get returns in the form of dividends and capital gains from the sale of shares is more excellent. Research by Tarmidi, Pramukty, \& Akbar (2020) shows that NPM has a positive and significant effect on stock prices.

\section{$>$ The Effect of Return on Equity on stock prices}

ROE has a coefficient of 0.169 , meaning that ROE has a positive effect on stock prices in infrastructure, utility and transportation companies listed on the Indonesia Stock Exchange. When ROE increases by $1 \%$, the share price will increase by $\mathrm{Rp}$. 0.169 . It shows that ROE is directly proportional to stock prices. The ROE Probability value is 0.0241 , which is smaller than sig t 0.05 so that ROE has a significant effect on stock prices, meaning that ROE has a positive and significant effect on stock prices. Signalling theory states that investors will capture information from companies as a good signal or a bad signal. In the company's financial ratios, ROE is information. The higher the ROE value of a company, the better because investors will catch this as a good signal so that an increase will follow it in stock prices. Usman, Haymans, \& Hutahayan's (2020) research shows that ROE has a positive and significant effect on stock prices.

\section{The effect of Price Earning ratio on stock prices}

PER has a coefficient of 0.34 meaning that PER has a positive effect on stock prices in infrastructure, utility and transportation companies listed on the IDX so that when PER increases by $1 \%$, the stock price will increase by $\mathrm{Rp}$. 0.34. It shows that PER is directly proportional to the stock price. Prob PER value is smaller than 0.05 , namely 0.00 , so it can conclude that the effect of PER on stock prices is significant, meaning that PER has a positive and significant effect on stock prices. It is in line with the theory which states that the higher the PER, the higher the stock price.

\section{Earning growth as a moderating variable CR, DER,} TATO, NPM, ROE and PER on stock prices

Earning growth is only able to moderate by weakening the influence of NPM on stock prices significantly, but for other independent variables such as CR, DER, TATO, ROE and PER cannot moderate by earning growth.

Based on the test results, it is known that $33.68 \%$ means that the share price is influenced by CR, DER, TATO, NPM, ROE and PER of $33.68 \%$ in infrastructure, utility and transportation companies listed on the IDX and the remaining $66.32 \%$ is affected by other factors. These results indicate that in making decisions, investors consider the level of share prices, the rate of return that will be received in the future, as well as the capabilities of other liquid assets.

\section{B. Suggestions}

This study only uses the current ratio, debt to equity ratio, total assets turnover, net profit margin, return on equity, and price earning ratio as independent variables. Even better. Besides, researchers can also add years of research.

\section{REFERENCES}

[1]. Afiff, S., \& Anantadjaya, S. P. (2013). CSR \& Performance: Any Evidence from Indonesian LQ45, 2(1), 85-102. Retrieved from http://papers.ssrn.com/abstract=2220242.

[2]. Ali, Muhammad. (2017). Kamus Lengkap Bahasa Indonesia Moderen. Jakarta: Penerbit Pustaka Amani.

[3]. Alwi, Iskandar. (2003). Pasar Modal: Teori dan Aplikasi (pp. 87-88). Jakarta: Nasindo Internusa.

[4]. Anoraga, Pandji \& Piji Pakarti. (2001). Pengantar Pasar Modal (pp. 63). Jakarta: PT Rineka Cipta.

[5]. Arikunto, Suharsimi. (2002). Prosedur Suatu Penelitian: Pendekatan Praktek (pp. 148). Jakarta: Rineka Cipta 
[6]. Astuty, P. (2017). The influence of fundamental factors and systematic risk to stock prices on companies listed in the Indonesian stock exchange. European Research Studies Journal, 20(4), 230-240. https://doi.org/10.35808/ersj/830

[7]. Blazenko, G. W., \& Fu, Y. (2013). Value versus growth in dynamic equity investing. Managerial Finance, 39(3), 272-305. https://doi.org/10.1108/03074351311302809

[8]. Basuki, Agus Tri. (2015). Regresi Dalam Penelitian Ekonomi dan Bisnis (pp. 135-153). Yogyakarta: Danisa Media.

[9]. Dananti, K., \& Cahjono, M. P. (2017). The Best Indicator of Capital Structure to Predict the Firm's Performance. Review of Integrative Business and Economics Research, 6(4), 317

[10]. Djazuli, Atim. (2015). The Relevance of Leverage, Profitability, Market Performance, and Macroeconomic to Stock Price. Journal. Faculty of Economic and Business, University of Brawijaya: Malang, Indonesia.

[11]. Gujarati, Damodar N (2012). Dasar-Dasar Ekonometrika Buku 2 Edisi 5. Jakarta: Salemba Empat. h.255.

[12]. Fahmi, Irham. (2012). Pengantar Pasar Modal (pp. 34). Bandung: Alfabeta.

[13]. Hada, T. (2014). Financial Statements, Source of Information for Financial Investments at the Bucharest Stock Exchange. Land Forces Academy Review, 19(1), 90-98.

[14]. Handayani, H., Muharam, H., Mawardi, W., \& Robiyanto, R. (2018). Determinants of the Stock Price Volatility in the Indonesian Manufacturing Sector. International Research Journal of Business Studies, 11(3), 179-193. https://doi.org/10.21632/irjbs.11.3.179-193

[15]. Harahap, Sofyan Syafri. (2010). Analisis Kritis atas Laporan Keuangan (10 ${ }^{\text {th. }}$, pp. 123-309). Jakarta: Penerbit PT Rajagrafindo Persada.

[16]. Herawati, A., \& Putra, A. S. (2018). The influence of fundamental analysis on stock prices: The case of food and beverage industries. European Research Studies Journal, 21(3), 316-326. https://doi.org/10.35808/ersj/1063

[17]. Hermuningsih, Sri. (2012). Pasar Modal Indonesia (hal. 80). Yogyakarta: UPP STIM YKPN.

[18]. Idris, I., \& Bala, H. (2015). Firms' Specific Characteristics and Stock Market Returns (Evidence from Listed Food and beverages Firms in Nigeria). Research Journal of Finance and Accounting, 6(16), 188-201.

[19]. Jogiyanto. (2008). Teori Portofolio dan Analisis Investasi (pp. 141). Yogyakarta: BPFE Universitas Gajah Mada.

[20]. Jumingan. (2014). Analisa Laporan Keuangan ( $5^{\text {th }}$., pp. 239). Jakarta: Bumi Aksara.

[21]. Kasmir. (2014). Pengantar Manajemen Keuangan (pp. 134). Jakarta: Kencana Persada Media Group.

[22]. Keown, Arthur J, David F Scott Jr, John D Martin, \& J William Petty (trans). (2001). Dasar-dasar
Manajemen Keuangan ( $7^{\text {th }}$ ed., pp. 136). Jakarta: Salemba Empat.

[23]. Kurniaty, S., Handayani, S. R., \& Rahayu, S. M. (2018). Stock return and financial performance as moderation variable in the influence of good corporate governance towards corporate value. Asian Journal of Accounting Research, 4(1), 18-34. https://doi.org/10.1108/ajar-07-2018-0021

[24]. Lahindah, L. (2011). Rev. Integr. Bus. Econ. Res. Vol 3(1) 42. 3(1), 42-52.

[25]. Lamuda, I. (2017). The Effects of Firm Size and Profitability on Banking Industry: Evidence from Indonesia Stock Exchange Ilyas LAMUDA, 11(4), 1214-1220.

[26]. Legowo, Herman \& Machfoedz, Mas'ud. (2002). Efisiensi Pasar Modal Perbandingan Pada Dua Periode Yang Berbeda Dalam Pasar Modal Indonesia. Bunga Rampai Kajian Teori Keuangan. Yogyakarta: BPFE - UGM.

[27]. Ligocká, M., \& Stavárek, D. (2019). the Relationship Between Financial Ratios and the Stock Prices Selected. 67(1), 299-307.

[28]. Mangesti Rahayu, S., Suhadak, \& Saifi, M. (2019). The reciprocal relationship between profitability and capital structure and its impacts on the corporate values of manufacturing companies in Indonesia. International Journal of Productivity and Performance Management, 69(2), 236-251. https://doi.org/10.1108/IJPPM-05-2018-0196

[29]. Manoppo, C. P. (2015). The Influence of Roa, Roe, Ros, and Eps on Stock Price. Jurnal Riset Ekonomi, Manajemen, Bisnis Dan Akuntansi, 3(4), 691-697.

[30]. Moeljadi. (2006). Manajemen Keuangan. Pendekatan Kuantitatif dan Kualitatif (1 ed., pp. 69). Malang: Bayu Media Publishing.

[31]. Mohammad Khan Ghauri, S. (2014). Determinants of changes in share prices in banking sector of Pakistan. Journal of Economic and Administrative Sciences, 30(2), 121-130. https://doi.org/10.1108/jeas-05-20130014

[32]. Mulyadi. (2007). Sistem Perencanaan dan Pengendalian Manajemen ( $3^{\text {th }}$, pp. 2) Jakarta: Salemba Empat

[33]. Munawir, S. (2008). Analisis Laporan Keuangan ( $4^{\text {th }}$, 11., pp. 31-66). Yogyakarta: Liberty.

[34]. Nachrowi, D. N \& Usman H. (2006). Pendekatan Populer dan Praktis Ekonometrika Untuk analisis Ekonomi dan Keuangan. Jakarta: Universitas Indonesia.

[35]. Noor, Juliansyah. (2013). Penelitian Ilmu Manajamen (pp. 27). Jakarta: Prenadamedia Group.

[36]. Pražák, T., \& Stavárek, D. (2017). The Effect of Financial Ratios on Stock Price Development. Interdisciplinary Economics and Business Research, 43(August), 3.

[37]. Purwanto, P., \& Agustin, J. (2017). Financial performance towards the value of firms in basic and chemicals industry. European Research Studies Journal, 20(2), 443-460. https://doi.org/10.35808/ersj/652. 
[38]. Rahardjo, Budi. (2009). Laporan Keuangan Perusahaan (2 $2^{\text {th }}$ ed., pp. 40-151). Yogyakarta: UGM Press.

[39]. Raju, M. A. (2017). Impact of macroeconomic variables on the stock performance of select companies in the manufacturing industry. International Journal of Economic Research, 14(8), 321-328.

[40]. Rochaety, Ety, Ratih Tresnawaty \& Abdul Madjid Latief. (2007). Metodologi. Penelitian Bisnis ( $1^{\text {st }}$ ed., pp. 66). Jakarta: Penerbit Mitra Wacana Media.

[41]. Saji, T. G., \& Harikumar, S. (2015). Earnings Growth and Value Premium: The Indian Experience. Vikalpa, 40(4), 444-454. https://doi.org/10.1177/0256090915608542

[42]. Samsul, Mohamad. (2006). Pasar Modal dan Manajemen Portofolio. Jakarta: Erlangga.

[43]. Sartono, Agus. (2000). Manajemen Keuangan, Teori dan Aplikasi ( $2^{\text {nd }}$ ed., pp. 124). Yogyakarta: BPFE UGM.

[44]. Sinulingga, Sukaria. (2011). Metode Penelitian (pp. 73-151). Medan: USU Press.

[45]. Sjahrial (2009). Manajemen Keuangan ( $3^{\text {th }}$ ed., pp. 261). Jakarta: Mitra Wacana. Media.

[46]. Subing, H. J. T., Wedi Rusmawan Kusumah, R., \& Gusni. (2017). An empirical analysis of internal and external factors of stock pricing: Evidence from Indonesia. Problems and Perspectives in Management, 15(4), 178-187. https://doi.org/10.21511/ppm.15(41). 2017.02

[47]. Sugiyono. (2008). Statistik Untuk Penelitian (pp. $72-$ 80). Bandung: Alfabeta. h.80.

[48]. Suhadak, S., Mangesti Rahayu, S., \& Handayani, S. R. (2019). GCG, financial architecture on stock return, financial performance and corporate value. International Journal of Productivity and Performance Management. https://doi.org/10.1108/IJPPM-09-20170224

[49]. Sulistyanto, Sri. (2008). Manajemen Laba (Teori Dan Model Empiris) (hal. 75). Jakarta: Grasindo. hl.75.

[50]. Syahrial, Dermawan dan Djahotman Purba. (2013). Analisis Laporan Keuangan (hal. 137). Jakarta: Mitra Wacana Media

[51]. Tseng, K. C. (1982). the Impact of Inflation on Stock Price. Financial Review, 17(2), 90-90. https://doi.org/10.1111/j.1540-6288.1982.tb00117.x.

[52]. Umar, Husein. (2003). Metodologi Penelitian Untuk Skripsi dan Tesis Bisnis (pp. 30). Jakarta: PT. Gramedia Pustaka.

[53]. Vasconcelos, L. N. C. de, \& Martins, O. S. (2019). Value and growth stocks and shareholder value creation in Brazil. Revista de Gestão, 26(3), 293-312. https://doi.org/10.1108/rege-12-2018-0127

[54]. Velankar, N., Chandani, A., \& Ahuja, A. K. (2017). Impact of EPS and DPS on Stock price: A Study of Selected Public Sector Banks of India. Prestige International Journal of Management \& ITSanchayan, 6(1), 111-121. Retrieved from http://pjitm.com/Doc/jan-july2017/PAPER8.pdf
[55]. Wang, J. (2013). Accounting Information and Stock Price Reaction of Listed Companies - Empirical Evidence from 60 Listed Companies in Shanghai Stock Exchange. Journal of Business \& Management, 2(2), 11-21. https://doi.org/10.12735/jbm.v2i2p11.

[56]. Weston, Fred, J. (1995). Manajemen Keuangan $\left(9^{\text {th }}\right.$., pp. 26-27). Yogyakarta: Penerbit BPFE.

[57]. Widarjono, Agus. (2013). Ekonometrika Pengantar dan Aplikasinya Disertai Panduan Eviews, $\left(4^{\text {td }}\right.$ ed., pp. 65). Yogyakarta: UPP STIM YKPN.

[58]. Wijaya, J. A. (2015). The Effect of Financial Ratios toward Stock Returns among Indonesian Manufacturing Companies. IBuss Management, 3(2), 261-271.

[59]. Wijaya, Marvin \& Yustina, Andi Ina. (2015). The Impact of Financial Ratio Toward Stock Price: Evidence from Banking Companies. Journal. Accounting Study Program Faculty of Business: President University. Indonesia. https://finance.yahoo.com www.idx.co.id 